\title{
Effect of the dose of exogenous fibrolytic enzyme preparations on preingestive fiber hydrolysis, ruminal fermentation, and in vitro digestibility of bermudagrass haylage
}

\author{
J. J. Romero, ${ }^{1}$ M. A. Zarate, and A. T. Adesogan ${ }^{2}$ \\ Department of Animal Sciences, Institute of Food and Agricultural Sciences, University of Florida, Gainesville 32608
}

\begin{abstract}
Our objectives were to evaluate the effects of the dose rates of 5 Trichoderma reesei and Aspergillus oryzae exogenous fibrolytic enzymes (EFE; 1A, 2A, 11C, 13D, and $15 \mathrm{D}$ ) on in vitro digestibility, fermentation characteristics, and preingestive hydrolysis of bermudagrass haylage and to identify the optimal dose of each EFE for subsequent in vitro and in vivo studies. In experiment 1, EFE were diluted in citrate-phosphate buffer ( $\mathrm{pH}$ 6) and applied in quadruplicate in each of 2 runs at $0 \times$ (control), $0.5 \times, 1 \times, 2 \times$, and $3 \times$; where $1 \times$ was the respective manufacturer-recommended dose $(2.25$, $2.25,10,15$, and $15 \mathrm{~g}$ of EFE $/ \mathrm{kg}$ of dry matter). The suspension was incubated for $24 \mathrm{~h}$ at $25^{\circ} \mathrm{C}$ and for a further $24 \mathrm{~h}$ at $39^{\circ} \mathrm{C}$ after the addition of ruminal fluid. In experiment 2, a similar approach to that in experiment 1 was used to evaluate simulated preingestive effects, except that sodium azide $(0.02 \% \mathrm{wt} / \mathrm{vol})$ was added to the EFE solution. The suspension was incubated for 24 $\mathrm{h}$ at $25^{\circ} \mathrm{C}$ and then $15 \mathrm{~mL}$ of water was added before filtration to extract water-soluble compounds. For both experiments, data for each enzyme were analyzed separately as a completely randomized block design with a model that included effects of EFE dose, run, and their interaction. In experiment 1, increasing the EFE dose rate nonlinearly increased the DM digestibility of $1 \mathrm{~A}$, $2 \mathrm{~A}, 11 \mathrm{C}$, and $13 \mathrm{D}$ and the neutral detergent fiber digestibility (NDFD) of 1A, 2A, 11C, and 13D. Optimal doses of $1 \mathrm{~A}, 2 \mathrm{~A}, 11 \mathrm{C}, 13 \mathrm{D}$, and $15 \mathrm{D}$, as indicated by the greatest increases in NDFD at the lowest dose tested, were $2 \times, 2 \times, 1 \times, 0.5 \times$, and $0.5 \times$, respectively. Increasing the dose rate of $2 \mathrm{~A}, 11 \mathrm{C}$, and $13 \mathrm{D}$ nonlinearly increased concentrations of total volatile fatty acids and propionate $(\mathrm{m} M)$, decreased their acetate-to-propionate ratios and linearly decreased those of samples treated with $1 \mathrm{~A}$ and $15 \mathrm{D}$. In experiment 2, increasing the dose
\end{abstract}

\footnotetext{
Received April 24, 2014.

Accepted September 4, 2014.

${ }^{1}$ Current address: Department of Crop Science, North Carolina State University, Raleigh, 1104A Williams Hall, Raleigh, NC 27695-

${ }^{2}$ Corresponding author: adesogan@ufl.edu
} 7620 . rate of each EFE nonlinearly decreased concentrations of netural detergent fiber; also, increasing the dose rate of $1 \mathrm{~A}, 2 \mathrm{~A}, 11 \mathrm{C}$, and $1 \mathrm{D}$ nonlinearly increased concentrations of water-soluble carbohydrates and free ferulic acid $(\mu \mathrm{g} / \mathrm{g})$. Application of increasing doses of the EFE increased NDF hydrolysis, NDFD, and ruminal fluid fermentation of bermudagrass haylage, but the optimal dose varied with the EFE.

Key words: fibrolytic enzyme, dairy cattle, bermudagrass, in vitro digestibility, dose

\section{INTRODUCTION}

Warm-season grasses are extensively used for cattle production in the southeast United States. Bermudagrass is the most important of such grasses that is used for cattle production (Newman, 2007), but as with other warm-season grasses, the quality of bermudagrass is low (Hanna and Sollenberger, 2007). Exogenous fibrolytic enzyme (EFE) treatment has been proposed as a method to improve forage quality and animal performance, but results of published studies have been equivocal (Adesogan et al., 2014). Various enzyme, animal, feed, and management factors influence the efficacy of fibrolytic EFE (Beauchemin et al., 2003; Adesogan et al., 2014), many of which are challenging to control. One factor that is easily controlled is the dose of the EFE. To our knowledge, only 2 studies (Dean et al., 2005; Krueger et al., 2008) have been conducted on effects of the dose of $\mathrm{EFE}$ on the nutritive value of bermudagrass. Dean et al. (2005) reported that 48-h in vitro NDF digestibility (NDFD) increased quadratically with increasing doses of 1 of 3 cellulase-xylanase EFE applied at the point of ensiling to a 5 -wk regrowth of Tifton 85 bermudagrass. Krueger et al. (2008) reported that applying increasing doses of an EFE with high esterase activity to Coastal or Tifton 85 bermudagrass hay had no effect on 6-, 24-, and 48-h in vitro NDFD, except for a linear increase in 6-h NDFD of the Tifton 85 cultivar. More studies are needed to examine effects of EFE dose rates on the quality of bermudagrass hay, silage, and haylage due to the important role of these forages in the diets of dairy and beef cattle in the southeast United States. This is 
because EFE can be ineffective if applied in insufficient or excessive amounts (Sanchez at al., 1996; Beauchemin et al., 2004). Low doses do not fully exploit the hydrolytic potential of EFE, especially during short incubation times. In contrast, excessively high doses decrease availability of substrates for catalysis or accessibility of substrates to these sites by crowding the substrate surface, which reduces the enzymatic hydrolysis rate (Bommarius et al., 2008). In the rumen, competition between excessively high doses of EFE and ruminal endogenous cellulolytic bacterial enzymes for substrates can decrease fiber digestibility (Nsereko et al., 2002) and consequently reduce animal performance (Kung et al., 2000). Therefore, optimization of the EFE dose is critical for using EFE to improve the digestibility of forages.

The objective of our study was to determine the optimum dose of $5 \mathrm{EFE}(1 \mathrm{~A}, 2 \mathrm{~A}, 11 \mathrm{C}, 13 \mathrm{D}$, and 15D) that were selected as the most promising of 12 candidates from 3 companies at improving the NDFD of bermudagrass haylage (BH; Romero et al., in press). The hypothesis was that increasing the dose of each EFE would increase the NDFD of BH in a quadratic manner.

\section{MATERIALS AND METHODS}

\section{Bermudagrass Substrate}

An established stand of bermudagrass (Cynodon dactylon cultivar Tifton 85) in Alachua, Alachua County, Florida, was staged in June 2010, by mowing to a 4-cm stubble and removing the residue. The field was fertilized subsequently with $\mathrm{N}(95 \mathrm{~kg} / \mathrm{ha})$ and the grass was allowed to regrow for 4-wk such that the harvest day was July 7, 2010. On harvest day, the grass was mowed within $1 \mathrm{~d}$ to a $4-\mathrm{cm}$ stubble with a Claas 3500 mower conditioner (Claas North America, Omaha, NE). The grass was wilted for $2.5 \mathrm{~h}$ in the windrow and then rolled into round $280-\mathrm{kg}$ round bales without inoculant addition. Bales were wrapped with 7 layers of $6-\mathrm{mm}$ plastic and ensiled for $53 \mathrm{~d}$. Ensiled bermudagrass was chosen over hay because it is more typically used in this form by dairy producers due to the high humidity and frequent summer rainfall in Florida (Staples, 2003). Representative haylage samples were collected as substrate for our study, dried at $60^{\circ} \mathrm{C}$ for $48 \mathrm{~h}$, and ground to pass the 1-mm screen of a Wiley mill (Arthur H. Thomas, Philadelphia, PA). The haylage had $49.4 \%$ of $\mathrm{DM}$ and 93.5, 68.1, 34.2, 3.7, and $18.7 \%$ of $\mathrm{OM}$, $\mathrm{NDF}, \mathrm{ADF}, \mathrm{ADL}$, and $\mathrm{CP}$, respectively (DM basis).

\section{Enzymes}

Five previously selected (Romero et al., in press) commercial and experimental EFE preparations pro- vided by 3 manufacturers were examined at 4 doses $(0 \times, 0.5 \times, 1 \times$, and $2 \times$, where $1 \times$ was the manufacturer's recommended dose). Table 1 lists the enzymatic activities and protein concentrations, form, doses, and biological sources of the EFE preparations. Endoglucanase (EC 3.2.1.4), exoglucanase (EC 3.2.1.91), xylanase (EC 3.2.1.8), and $\beta$-glucosidase (EC 3.2.1.21) activities were quantified using carboxymethyl cellulose, avicel, oat-spelt xylan, and cellobiose as artificial substrates, respectively (Wood and Bhat, 1988). Enzymes were incubated with the respective substrates for 15, 120, 5, and $30 \mathrm{~min}$ as suggested by Colombatto and Beauchemin (2003). Glucose was used as the standard for measuring endoglucanase, exoglucanase, and $\beta$-glucosidase activity, whereas xylose was used as that for measuring xylanase activity. Ferulic acid esterase (EC 3.1.1.73) activity was measured using ethyl ferulate as the substrate with an incubation period of 5 min with the enzymes (Lai et al., 2009). All activities were measured at $39^{\circ} \mathrm{C}$ and a $\mathrm{pH}$ of 6 to mimic conditions in the rumen as previously recommended for enzyme studies for lactating dairy cows (Colombatto and Beauchemin, 2003). Activities measured at $20^{\circ} \mathrm{C}$ and $\mathrm{pH} 6$ were included as a reference for the simulated preingestive hydrolysis assay that was conducted at $25^{\circ} \mathrm{C}$. Protein concentration was measured using the Bio-Rad protein assay (Bradford, 1976) with BSA as the standard (Bio-Rad Laboratories, Hercules, CA).

\section{In Vitro Ruminal Digestibility (Experiment 1)}

All EFE were evaluated with a 24-h in vitro ruminal digestibility assay (Goering and Van Soest, 1970) using $\mathrm{BH}$ as the substrate. As described by Krueger and Adesogan (2008), EFE were diluted in $0.1 M$ citratephosphate buffer ( $\mathrm{pH} 6$ ) and $2 \mathrm{~mL}$ of the solution containing the requisite EFE dose was applied to $0.5 \mathrm{~g}$ of substrate. The $0 \times$ (control) treatment consisted only of the citrate-phosphate buffer and the substrate. Treatments were applied in quadruplicate to the substrate in $100-\mathrm{mL}$ polypropylene tubes capped with a rubber stopper fitted with a one-way gas-release valve. Two blank tubes per treatment, containing no substrate, were used to correct for the substrate contribution from the ruminal inoculum. Tubes were tapped gently to ensure proper mixing of EFE solution with the substrate and the suspensions were subsequently incubated at $25^{\circ} \mathrm{C}$ for $24 \mathrm{~h}$ before addition of buffered ruminal fluid. The ruminal fluid was representatively collected by aspiration $3 \mathrm{~h}$ after feeding $(0800 \mathrm{~h})$ from 2 nonlactating, nonpregnant, ruminally cannulated Holstein cows consuming a ration consisting of coastal bermudagrass hay ad libitum supplemented with corn $(0.45 \mathrm{~kg})$, cottonseed hulls $(0.46 \mathrm{~kg})$, soybean meal $(0.90 \mathrm{~kg})$, and a 
Table 1. Endoglucanase, xylanase, exoglucanase, $\beta$-glucosidase $(\mu \mathrm{mol}$ of sugar released $/ \mathrm{min} \times \mathrm{g})$ and ferulic acid esterase (nmol of ferulic acid released/min $\times \mathrm{g}$ ) activities at 20 and $39^{\circ} \mathrm{C}$, protein concentration $(\mathrm{mg} / \mathrm{g})$, form, dose ( $\mathrm{g} / \mathrm{kg}$ of bermudagrass $\mathrm{DM})$, and biological source of exogenous fibrolytic enzyme (EFE) preparations (1A, 2A, 11C, 13D, 15D) applied to bermudagrass haylage

\begin{tabular}{|c|c|c|c|c|c|}
\hline \multirow[b]{2}{*}{ Parameter } & \multicolumn{5}{|c|}{$\mathrm{EFE}$} \\
\hline & $1 \mathrm{~A}$ & $2 \mathrm{~A}$ & $11 \mathrm{C}$ & $13 \mathrm{D}$ & $15 \mathrm{D}$ \\
\hline Biological source & Trichoderma reesei & T. reesei & T. reesei & Aspergillus oryzae & A. oryzae \\
\hline \multicolumn{6}{|l|}{ Activity at $20^{\circ} \mathrm{C}$} \\
\hline Endoglucanase & 885 & 1,654 & 1,019 & 100 & 88 \\
\hline Xylanase & 1,313 & 28,800 & 1,815 & 105 & 3,640 \\
\hline Exoglucanase & 0.76 & 0.59 & 0.49 & 0.38 & 0.36 \\
\hline$\beta$-Glucosidase & 3.4 & 10.1 & 3.9 & 1.0 & 0.02 \\
\hline Ferulic acid esterase & 1.14 & 1.46 & 2.91 & 2.35 & 1.20 \\
\hline \multicolumn{6}{|l|}{ Activity at $39^{\circ} \mathrm{C}$} \\
\hline Endoglucanase & 1,693 & 3,624 & 1,506 & 286 & 70 \\
\hline Xylanase & 1,276 & 29,301 & 1,703 & 86 & 6,499 \\
\hline Exoglucanase & 1.68 & 0.84 & 0.97 & 0.29 & 0.29 \\
\hline$\beta$-Glucosidase & 10.1 & 11.7 & 12.7 & 1.9 & 0.1 \\
\hline Ferulic acid esterase & 2.18 & 1.46 & 6.30 & 2.35 & 2.57 \\
\hline Protein concentration & 65.3 & 111 & 81.1 & 18 & 28.3 \\
\hline \multicolumn{6}{|l|}{ Dose } \\
\hline $0.5 \times$ & 1.17 & 1.17 & 5.2 & 7.8 & 7.8 \\
\hline $1 \times$ & 2.33 & 2.33 & 10.4 & 15.6 & 15.6 \\
\hline $2 \times$ & 4.66 & 4.66 & 20.8 & 31.2 & 31.2 \\
\hline $3 \times$ & 6.99 & 6.99 & 31.2 & 46.8 & 46.8 \\
\hline
\end{tabular}

vitamin-mineral mix (35.8 g; DM basis). The ruminal fluid collection protocol was approved by the University of Florida, Institute of Food and Agricultural Sciences, Animal Research Committee. The ruminal fluid collected was filtered through 4 layers of cheesecloth and mixed with prewarmed artificial saliva (Goering and Van Soest, 1970). Buffered ruminal fluid $(52 \mathrm{~mL})$ was dispensed into prewarmed tubes. Tubes were incubated at $39^{\circ} \mathrm{C}$ for $24 \mathrm{~h}$. Fermentation was terminated by placing the tubes on ice. Tube contents were filtered through previously dried $\left(60^{\circ} \mathrm{C}\right.$ for $\left.48 \mathrm{~h}\right)$ and weighed 125-mm Whatman No. 451 paper (Fisher Scientific, Pittsburgh, PA). Filtrate and residues were collected for further analysis. Residues were dried at $60^{\circ} \mathrm{C}$ for 48 $\mathrm{h}$, weighed, and analyzed for NDF (Van Soest et al., 1991) and ADF (AOAC International, 2000) sequentially using an Ankom 200 Fiber Analyzer (Ankom, Macedon, NY). No sodium sulfite was used for the NDF analysis. Hemicellulose (HEM) was calculated as the difference between NDF and ADF. Residue weights and their fiber concentrations were used to calculate true digestibility of DM, NDF, HEM, and ADF (DMD, HEMD, and ADFD; Mertens, 2007). Filtrate samples were analyzed for $\mathrm{pH}$ using an Accumet XL25 pH meter with an automatic temperature correction feature (Fisher Scientific), acidified with $50 \% \mathrm{H}_{2} \mathrm{SO}_{4}(1 \% \mathrm{vol} /$ vol) and centrifuged at $8,000 \times g$ for $20 \mathrm{~min}$ at $4^{\circ} \mathrm{C}$. The supernatant was frozen $\left(-20^{\circ} \mathrm{C}\right)$ and subsequently analyzed for concentrations of VFA (Muck and Dickerson, 1988) using a Merck Hitachi Elite LaChrome High Performance Liquid Chromatograph system (Hitachi
L2400, Tokyo, Japan) fitted with a Bio-Rad Aminex HPX-87H column (Bio-Rad Laboratories, Hercules, CA). Ammonia-N was determined with a Technicon Auto Analyzer (Technicon, Tarrytown, NY) and an adaptation of the Noel and Hambleton (1976) procedure that involved colorimetric $\mathrm{N}$ quantification.

\section{Preingestive Fiber Hydrolysis (Experiment 2)}

The same EFE doses examined in experiment 1 were tested in this experiment to ascertain their effects on preingestive hydrolysis of $\mathrm{BH}$. In experiment 2 , a similar approach as that in experiment 1 was used to evaluate simulated preingestive effects, except that $50-\mathrm{mL}$ centrifuge tubes were used and sodium azide $(0.02 \% \mathrm{wt} / \mathrm{vol})$ was added to the EFE solution to prevent microbial degradation of substrate (Krueger and Adesogan, 2008).Two blank tubes per treatment, containing no substrate, were included as EFE blanks. After the incubation at $25^{\circ} \mathrm{C}, 15 \mathrm{~mL}$ of double-distilled water were added and tubes were shaken for $1 \mathrm{~h}$ at 260 oscillations/min with an Eberbach Reciprocating Shaker Model 6000 (Eberbach Corporation, Ann Arbor, MI) to extract water-soluble compounds. Tubes were filtered through previously dried $\left(60^{\circ} \mathrm{C}\right.$ for $\left.48 \mathrm{~h}\right)$ and weighed 125-mm Whatman No. 451 filter paper (Fisher Scientific, Pittsburgh) and filtrate and residue samples were collected. Residues were dried at $60^{\circ} \mathrm{C}$ for $48 \mathrm{~h}$, weighed, and analyzed for NDF and ADF as described previously. Residue and sample dry weights and DM concentrations were used to calculate DM 
losses. Residue weights and their fiber concentrations were used to calculate fiber fraction concentrations. Filtrate samples were frozen $\left(-20^{\circ} \mathrm{C}\right)$ and subsequently analyzed for water-soluble carbohydrates (WSC; DuBois et al., 1956) and ferulic (FER) and p-coumaric acids (COU; Bio-Rad, 2011) using the HPLC system and the HPX-87H column described previously.

\section{Statistical Analyses}

Data for each EFE were analyzed separately. A randomized complete block design with 4 replicates per treatment and 2 runs was used to determine the effects of EFE preparations on digestibility and fermentation measures (experiment 1) and substrate DM and fiber disappearance and release of sugars and phenolic acids (experiment 2). Run was the blocking factor.

The model used to analyze digestibility, fermentation and preingestive hydrolysis data was

$$
\mathrm{Y}_{\mathrm{ijk}}=\mu+\mathrm{D}_{\mathrm{i}}+\mathrm{R}_{\mathrm{j}}+\mathrm{DR}_{\mathrm{ij}}+\mathrm{E}_{\mathrm{ijk}},
$$

where $\mu=$ general mean; $D_{i}=$ effect of dose $i ; R_{j}=$ effect of run $\mathrm{j} ; \mathrm{DR}_{\mathrm{ij}}=$ effect of the dose $\mathrm{i} \times$ run $\mathrm{j}$ interaction; and $\mathrm{E}_{\mathrm{ijk}}=$ experimental error.

The GLM procedure of SAS v.9.1 (SAS Institute Inc., Cary, NC) was used to analyze each EFE separately, because comparing dose rate effects among EFE was not of interest. Polynomial contrasts were used to determine dose effects and the Fisher's F-protected least significance difference test was used to determine the optimal dose. Both of these mean characterization and separation tests were considered necessary to properly interpret the results because they depict the polynomial trend and the optimal dose, respectively. The final decision on the optimal dose of the EFE for future in vitro and animal trials was defined as the least dose that resulted in a greater increase in NDFD than lower doses and a similar or greater response relative to higher doses. Neutral detergent fiber digestibility was chosen as the response of choice for selecting the optimal dose because of its correlation with DMI and milk production (Oba and Allen, 1999). Significance was declared at $P<0.05$ and tendencies at $P>0.05<0.10$.

\section{RESULTS AND DISCUSSION}

\section{Experiment 1: EFE Dose Effects on Measures of in Vitro Digestion and Fermentation}

EFE Dose Effects on Digestibility Measures. Increasing the dose of EFE $1 \mathrm{~A}$ linearly increased $(P$ $<0.01)$ HEMD and had a cubic effect $(P<0.05)$ on DMD and NDFD (Table 2). Compared with the con- trol, the $2 \times$ dose was the lowest dose that resulted in the greatest increases in NDFD and HEMD (7.4 and $11.5 \%$, respectively). This dose also resulted in the greatest increase in NDFD per unit of EFE 1A used (0.56\% NDFD per gram of EFE). Applying EFE 1A did not affect DMD, but the $2 \times$ and $3 \times$ doses resulted in greater DMD than the $0.5 \times$ dose. Applying increasing doses of EFE $1 \mathrm{~A}$ resulted in a cubic effect $(P<$ $0.05)$ on ADFD partly because its value decreased to a nadir when the $0.5 \times$ and $1 \times$ doses were applied $(-8.4$ and $-10.9 \%$, respectively; $P<0.05)$. The decrease in ADFD with increasing doses of EFE $1 \mathrm{~A}$ is probably attributable to the declining reactivity of residual cellulose during enzymatic hydrolysis due to the decrease in surface area and number of accessible chain ends or adsorption of inactive cellulase on the surface of cellulose (Zhang and Lynd, 2004). Yet, if the EFE dose is too low, the supply of auxiliary enzymes and proteins, such as swollenin, may be insufficient to remove barriers preventing increases in ADFD.

Applying increasing doses of EFE $2 \mathrm{~A}$ increased $(P$ $<0.05$, quadratic) DMD, NDFD, and HEMD (Table $2)$. The $2 \times$ dose was the lowest dose that resulted in the greatest $(P<0.05)$ increases in NDFD and HEMD (10.8 and $16.2 \%$, respectively), but the dose that gave the greatest increase in NDFD per unit of EFE 2A was $0.5 \times(1.97 \%$ NDFD units per gram of EFE). The choice of which dose to use depends on the desired objective. If the intent is to maximize NDFD, the $2 \times$ dose should be selected, whereas the $0.5 \times$ dose should be chosen from an efficiency standpoint, provided it is subsequently shown to provide an economic increase in animal performance. Increasing the dose of EFE 2A did not increase ADFD. Therefore, the EFE exerted its hydrolytic effect on HEM rather than ADF. Hemicellulose typically represents about half of the fiber concentration in grasses (Van Soest, 1994), and it was the fiber fraction most effectively hydrolyzed by adding EFE to BH (Romero et al., 2013).

Increasing the dose of EFE $11 \mathrm{C}$ increased ADFD $(P<0.01$, linear $)$ DMD $(P<0.01$, quadratic $)$, and NDFD and HEMD $(P<0.01$, cubic; Table 2$)$. The $1 \times$ dose was the lowest dose that resulted in the greatest increases in NDFD, HEMD, and ADFD (16.2, 22.6, and $6.7 \%$, respectively; $P<0.05$ ). The dose resulting in the greatest increase in NDFD per unit of EFE $11 \mathrm{C}$ was $0.5 \times(0.37 \%$ NDFD per gram of EFE). As was the case for EFE $1 \mathrm{~A}$ and $2 \mathrm{~A}$, EFE $11 \mathrm{C}$ had its greatest effects on the HEM fiber fraction. However, unlike EFE 1A and $2 \mathrm{~A}, 11 \mathrm{C}$ also increased ADFD when applied at $1 \times$ or $3 \times$. This may be because EFE $11 \mathrm{C}$ supplied more exoglucanases on an applied basis than the other EFE. Exoglucanase I is usually the most secreted enzyme protein in Trichoderma reesei $(60 \%)$ commercial prepa- 
Table 2. Effects of the dose of exogenous fibrolytic enzymes (EFE; 1A, 2A, 11C, 13D, and 15D, as described in Table 1) on in vitro true dry matter (DMD), neutral detergent fiber (NDFD), hemicellulose (HEMD), and acid detergent fiber (ADFD) digestibility of a 4-wk regrowth bermudagrass haylage (experiment 1)

\begin{tabular}{|c|c|c|c|c|}
\hline Dose & DMD (\%) & NDFD (\%) & HEMD (\%) & $\operatorname{ADFD}(\%)$ \\
\hline \multicolumn{5}{|l|}{ EFE $1 \mathrm{~A}$} \\
\hline $0 \times$ & $48.6^{\mathrm{abc}}$ & $35.1^{\mathrm{bc}}$ & $31.4^{\mathrm{c}}$ & $40.5^{\mathrm{a}}$ \\
\hline $0.5 \times$ & $47.7^{\mathrm{c}}$ & $35.0^{\mathrm{bc}}$ & $32.5^{\mathrm{bc}}$ & $37.1^{\mathrm{bc}}$ \\
\hline $1 \times$ & $47.9^{\mathrm{bc}}$ & $34.2^{\mathrm{c}}$ & $31.8^{\mathrm{c}}$ & $36.1^{\mathrm{c}}$ \\
\hline $2 \times$ & $49.7^{\mathrm{a}}$ & $37.7^{\mathrm{a}}$ & $35.0^{\mathrm{a}}$ & $39.7^{\mathrm{a}}$ \\
\hline $3 \times$ & $49.0^{\mathrm{ab}}$ & $36.5^{\mathrm{ab}}$ & $33.8^{\mathrm{ab}}$ & $38.7^{\mathrm{ab}}$ \\
\hline SEM & 0.40 & 0.73 & 0.67 & 0.76 \\
\hline Contrast $^{1}$ & $\mathrm{C}^{* *}$ & $\mathrm{C}^{*}$ & $\mathrm{~L}^{* *}$ & $\mathrm{C}^{* *}$ \\
\hline Linear & 0.019 & 0.009 & 0.001 & 0.824 \\
\hline Quadratic & 0.863 & 0.846 & 0.187 & 0.017 \\
\hline Cubic & 0.004 & 0.014 & 0.082 & 0.001 \\
\hline \multicolumn{5}{|l|}{ EFE $2 \mathrm{~A}$} \\
\hline $0 \times$ & $48.6^{\mathrm{b}}$ & $35.1^{\mathrm{c}}$ & $31.4^{\mathrm{c}}$ & $40.5^{\mathrm{ab}}$ \\
\hline $0.5 \times$ & $49.7^{\mathrm{ab}}$ & $37.4^{\mathrm{b}}$ & $34.8^{\mathrm{b}}$ & $40.8^{\mathrm{ab}}$ \\
\hline $1 \times$ & $50.1^{\mathrm{a}}$ & $38.0^{\mathrm{ab}}$ & $34.7^{\mathrm{b}}$ & $41.8^{\mathrm{a}}$ \\
\hline $2 \times$ & $50.6^{\mathrm{a}}$ & $38.9^{\mathrm{a}}$ & $36.5^{\mathrm{a}}$ & $41.4^{\mathrm{a}}$ \\
\hline $3 \times$ & $50.4^{\mathrm{a}}$ & $38.0^{\mathrm{ab}}$ & $36.1^{\mathrm{ab}}$ & $39.2^{\mathrm{b}}$ \\
\hline SEM & 0.42 & 0.67 & 0.64 & 0.73 \\
\hline Contrast & $\mathrm{Q}^{*}$ & $\mathrm{Q}^{* *}$ & $\mathrm{Q}^{* *}$ & $\mathrm{Q}^{*}$ \\
\hline Linear & 0.002 & 0.002 & $<0.001$ & 0.184 \\
\hline Quadratic & 0.033 & 0.002 & 0.001 & 0.016 \\
\hline Cubic & 0.614 & 0.627 & 0.298 & 0.641 \\
\hline \multicolumn{5}{|l|}{ EFE $11 C$} \\
\hline $0 \times$ & $48.6^{\mathrm{c}}$ & $35.1^{\mathrm{c}}$ & $31.4^{\mathrm{c}}$ & $40.5^{\mathrm{c}}$ \\
\hline $0.5 \times$ & $50.4^{\mathrm{b}}$ & $38.9^{\mathrm{b}}$ & $35.4^{\mathrm{b}}$ & $42.2^{\mathrm{bc}}$ \\
\hline $1 \times$ & $51.4^{\mathrm{ab}}$ & $40.8^{\mathrm{a}}$ & $38.5^{\mathrm{a}}$ & $43.2^{\mathrm{ab}}$ \\
\hline $2 \times$ & $51.9^{\mathrm{a}}$ & $40.4^{\mathrm{ab}}$ & $38.5^{\mathrm{a}}$ & $42.3^{\mathrm{abc}}$ \\
\hline $3 \times$ & $52.2^{\mathrm{a}}$ & $41.7^{\mathrm{a}}$ & $39.4^{\mathrm{a}}$ & $44.3^{\mathrm{a}}$ \\
\hline SEM & 0.40 & 0.66 & 0.58 & 0.75 \\
\hline Contrast & $\mathrm{Q}^{* *}$ & $\mathrm{C}^{* *}$ & $\mathrm{C}^{* *}$ & $\mathrm{~L}^{* *}$ \\
\hline Linear & $<0.001$ & $<0.001$ & $<0.001$ & 0.003 \\
\hline Quadratic & 0.003 & 0.001 & $<0.001$ & 0.607 \\
\hline Cubic & 0.172 & 0.004 & 0.004 & 0.061 \\
\hline \multicolumn{5}{|l|}{ EFE 13D } \\
\hline $0 \times$ & $48.6^{\mathrm{b}}$ & $35.1^{\mathrm{c}}$ & $31.4^{\mathrm{c}}$ & $40.5^{\mathrm{b}}$ \\
\hline $0.5 \times$ & $51.1^{\mathrm{a}}$ & $39.7^{\mathrm{a}}$ & $37.5^{\mathrm{a}}$ & $42.7^{\mathrm{a}}$ \\
\hline $1 \times$ & $50.7^{\mathrm{a}}$ & $38.5^{\mathrm{a}}$ & $37.0^{\mathrm{ab}}$ & $42.9^{\mathrm{a}}$ \\
\hline $2 \times$ & $49.5^{\mathrm{b}}$ & $37.0^{\mathrm{b}}$ & $35.7^{\mathrm{b}}$ & $39.1^{\mathrm{b}}$ \\
\hline $3 \times$ & $51.2^{\mathrm{a}}$ & $39.1^{\mathrm{a}}$ & $37.5^{\mathrm{a}}$ & $40.8^{\mathrm{b}}$ \\
\hline SEM & 0.35 & 0.49 & 0.60 & 0.66 \\
\hline Contrast & $\mathrm{C}^{*}$ & $\mathrm{C}^{* *}$ & $\mathrm{C}^{* *}$ & $\mathrm{C}^{* *}$ \\
\hline Linear & 0.006 & 0.007 & $<0.001$ & 0.041 \\
\hline Quadratic & 0.300 & 0.069 & 0.001 & 0.446 \\
\hline Cubic & $<0.001$ & $<0.001$ & $<0.001$ & $<0.001$ \\
\hline \multicolumn{5}{|l|}{ EFE 15D } \\
\hline $0 \times$ & 48.6 & $35.1^{\mathrm{b}}$ & $31.4^{\mathrm{b}}$ & $40.5^{\mathrm{a}}$ \\
\hline $0.5 \times$ & 49.1 & $36.9^{\mathrm{a}}$ & $34.5^{\mathrm{a}}$ & $38.0^{\mathrm{b}}$ \\
\hline $1 \times$ & 49.2 & $35.9^{\mathrm{ab}}$ & $33.9^{\mathrm{a}}$ & $37.9^{\mathrm{b}}$ \\
\hline $2 \times$ & 48.8 & $36.2^{\mathrm{ab}}$ & $34.3^{\mathrm{a}}$ & $38.4^{\mathrm{b}}$ \\
\hline $3 \times$ & 48.9 & $35.2^{\mathrm{b}}$ & $33.3^{\mathrm{a}}$ & $37.7^{\mathrm{b}}$ \\
\hline SEM & 0.39 & 0.53 & 0.55 & 0.58 \\
\hline Contrast & n.s. & $\mathrm{Q}^{+}$ & $\mathrm{Q}^{* *}$ & $\mathrm{C}^{*}$ \\
\hline Linear & 0.845 & 0.580 & 0.108 & 0.018 \\
\hline Quadratic & 0.478 & 0.080 & 0.001 & 0.067 \\
\hline Cubic & 0.314 & 0.429 & 0.096 & 0.020 \\
\hline
\end{tabular}

${ }^{a-e}$ Means within an EFE treatment within a column with different superscripts differed $(P<0.05)$.

${ }^{1}$ Linear (L), quadratic (Q), cubic (C), not significant (n.s.).

${ }^{+} P<0.10,{ }^{*} P<0.05,{ }^{* *} P<0.01$.

rations and is arguably the most relevant enzyme in cellulose hydrolysis (Selig et al., 2008). Exoglucanases progressively cleave cellulose chains at the reducing and nonreducing ends to release cellobiose or glucose after the hydrolytic and oxidative cleavage of internal parts of the chain by endoglucanases (Zhang et al., 2006) and novel polysaccharide monooxygenases, respectively (Dimarogona et al., 2013). This enzymatic depolymer- 
ization is the rate-limiting step in cellulose hydrolysis (Zhang et al., 2006).

Applying EFE 13D at increasing doses had a cubic effect $(P<0.01)$ on all digestibility measures (Table 2 ) and $0.5 \times$ was the optimal dose for increasing DMD, NDFD, HEMD, and ADFD. This dose resulted in the greatest increases in these digestibility measures at the lowest dose tested $(5.14,13.1,19.4$, and $5.4 \%$, respectively) and elicited the greatest increase in NDFD per unit of EFE 13D (0.59\% per gram of EFE). Hemicellulose was the fiber fraction hydrolyzed to the greatest extent by 13D.

Increasing the dose of EFE $15 \mathrm{D}$ resulted in no effect $(P>0.05)$ on DMD, quadratic increases in NDFD $(P$ $<0.10$, tendency) and HEMD $(P<0.01)$, and cubic effects $(P<0.05)$ on ADFD (Table 2). The optimal dose for increasing NDFD and HEMD was $0.5 \times$ because the respective responses peaked and plateaued at this dose (5.1 and $9.9 \%$ ), respectively. The $0.5 \times$ dose also resulted in the greatest increase in NDFD per unit of EFE 15D (0.23\% per gram of EFE). However, applying all doses of EFE 15D decreased ADFD. The decreases in ADFD caused by EFE $15 \mathrm{D}$ suggest that it only degraded the most accessible and digestible amorphous cellulose fractions, leaving the more recalcitrant fractions undegraded. Furthermore, EFE 15D may have had the poorest effect on in vitro digestibility because it had a lower ratio of collective cellulase activities (endoglucanase, exoglucanase, and $\beta$-glucosidase) to xylanase activity than other EFE (0.01 vs. 1.43). However, previous results have shown poor relationships between EFE activities and in vitro digestibility measures (Colombatto et al., 2003; Eun and Beauchemin, 2008; Romero et al., in press). Whether such poor relationships are due to measuring activity with inappropriate substrates (Adesogan et al. 2014) or techniques (Colombatto and Beauchemin, 2003) is unknown. The poor relationships suggest the need for caution in using different enzyme activities to explain the in vitro digestibility responses.

EFE Dose Effects on Fermentation Measures. Increasing the dose of EFE $1 \mathrm{~A}$ had no effect on total VFA (TVFA), acetate, isobutyrate, valerate, and $\mathrm{NH}_{3} \mathrm{~N}$ concentrations but linearly reduced $(P<0.01)$ the acetate-to-propionate $(\mathbf{A}: \mathbf{P})$ ratio due to linearly increasing $(P<0.10$, tendency) propionate concentration. In addition, increasing the EFE $1 \mathrm{~A}$ dose caused cubic responses $(P<0.01)$ in butyrate and isovalerate concentrations and $\mathrm{pH}$ (Table 3). Butyrate concentration was decreased by increasing the dose of EFE $1 \mathrm{~A}$ $(P<0.05)$, with the nadir occurring at doses of $0.5 \times$ and $1 \times(-13.2$ and $-14.8 \%)$, respectively. This pattern reflects the decreases in ADFD when the same doses of EFE 1A were used because butyrate is one of the main VFA generated during fiber fermentation (Rinne et al., 1997). Isovalerate concentration increased with the $0.5 \times$ and $3 \times$ doses of EFE $1 \mathrm{~A}$. This probably indicates that the EFE increased ruminal protein degradation because isovalerate is a product of leucine deamination (Van Soest, 1994) and pepsin-like proteases were detected in the secretome of EFE from T. reesei (Romero et al., in press).

Increasing the dose of EFE $2 \mathrm{~A}$ had no effect on $\mathrm{NH}_{3} \mathrm{~N}$ concentration but it caused a linear increase on $\mathrm{pH}$ $(P<0.01)$ and a cubic effect on TVFA, acetate, propionate, butyrate, isobutyrate, isovalerate, and valerate concentration and A:P ratio $(P<0.05$; Table 3$)$. Total VFA concentration was increased $(P<0.05)$ by all doses of EFE $2 \mathrm{~A}$ except $2 \times$. This suggests EFE $2 \mathrm{~A}$ has great potential to increase energy supply in dairy cattle because TVFA provides $70 \%$ of the caloric requirements in ruminants (Bergman, 1990). This increase in TVFA was due mostly to corresponding increases in concentrations of propionate $(P<0.05 ; 11.0,15.6$, and $20.2 \%$ at $0.5 \times, 1 \times$, and $3 \times$, respectively), butyrate $(P$ $<0.05 ; 12.5$ and $9.4 \%$ at $0.5 \times$ and $1 \times$, respectively), and acetate $(P<0.05 ; 7.5 \%$ at $3 \times)$. The A:P ratio was decreased by increasing doses of EFE $2 \mathrm{~A}$ because the latter increased propionate concentrations but did not affect acetate concentration except at the $3 \times$ dose. This increased availability of propionate could provide valuable glucose precursors if it occurs in dairy cows fed enzyme-treated forages. Concentrations of isobutyrate and isovalerate were increased by applying EFE $2 \mathrm{~A}$ at doses of $0.5 \times, 1 \times$, and $3 \times(20.1,21.7$, and $39.2 \%$, respectively) and $0.5 \times, 1 \times, 2 \times$, and $3 \times(7.7,10.1,11.0$, and $18.3 \%$, respectively), but the $2 \times$ dose decreased valerate concentration $(-13.7 \%)$. The increase in concentration of branched-chained VFA suggests that, as in EFE 1A, EFE 2A also stimulated protein degradation. This did not result in greater $\mathrm{NH}_{3} \mathrm{~N}$ concentrations probably because the high $\mathrm{NH}_{3} \mathrm{~N}$ concentration (42.6 $\mathrm{mg} / \mathrm{dL}$ ) in the buffered ruminal fluid made detection of small changes in $\mathrm{NH}_{3} \mathrm{~N}$ concentration difficult.

Increasing the dose of EFE $11 \mathrm{C}$ had no effect on valerate concentration, increased butyrate concentration and $\mathrm{pH}(P<0.01$, quadratic $)$, and had a cubic effect on A:P ratio and concentrations of TVFA, acetate, propionate, isobutyrate, isovalerate, and $\mathrm{NH}_{3} \mathrm{~N}(P<$ 0.05; Table 3). Total VFA concentration was increased $(P<0.05)$ by applying EFE $11 \mathrm{C}$ at the $0.5 \times$ and $3 \times$ doses (8.2 and $8.6 \%$, respectively), due to corresponding increases in propionate concentration $(P<0.05)$ at the $0.5 \times, 1 \times$, and $3 \times$ doses $(14.7,9.2$, and $16.5 \%$, respectively). All doses of EFE $11 \mathrm{C}$ similarly decreased the A:P ratio, and butyrate concentration was only increased by the $3 \times$ dose (15.3\%). As for EFE $2 \mathrm{~A}$, the increased TVFA concentration due to applying EFE $11 \mathrm{C}$ has the potential to increase the supply of energy 
Table 3. Effects of the dose of exogenous fibrolytic enzymes (EFE; 1A, 2A, 11C, 13D, and 15D, as described in Table 1) on concentrations of total volatile fatty acids (TVFA), acetate, propionate, butyrate, isobutyrate, isovalerate, valerate, $\mathrm{NH}_{3} \mathrm{~N}$, acetate-to-propionate ratio (A:P), and $\mathrm{pH}$ of the filtrate obtained from fermentation of a 4 -wk regrowth of bermudagrass haylage (experiment 1 )

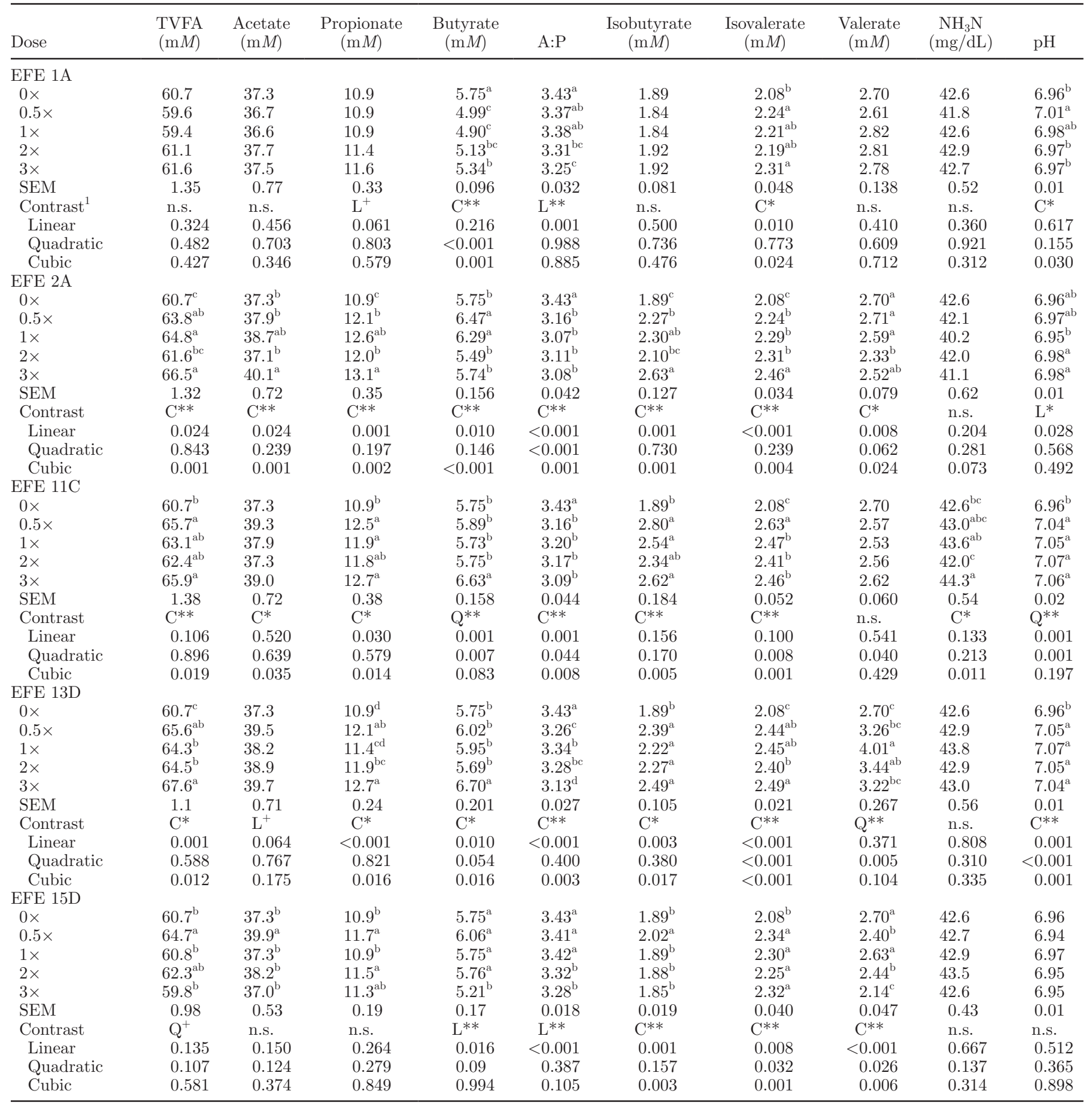

${ }^{\mathrm{a} e}$ Means within an EFE treatment within a column with different superscripts differed $(P<0.05)$.

${ }^{1}$ Linear (L), quadratic (Q), cubic (C), not significant (n.s.).

${ }^{+} P<0.10,{ }^{*} P<0.05,{ }^{* *} P<0.01$.

to lactating cows. Furthermore, the increased butyrate concentration may induce proliferation of ruminal epithelial growth, thus increasing the VFA absorption ca- pacity of the rumen (Gorka et al., 2009). Butyrate also provides building blocks for de novo synthesis of fat in the mammary gland (Mohammed et al., 2011); there- 
fore, applying EFE $11 \mathrm{C}$ at the $3 \times$ dose may increase milk fat concentration and or yield in lactating dairy cows. In addition, the $0.5 \times, 1 \times$, and $3 \times$ doses increased isobutyrate concentration by $48.2,34.4,23.8$, and $38.6 \%$ and the $0.5 \times, 1 \times, 2 \times$, and $3 \times$ doses increased isovalerate concentrations by $26.4,18.8,15.9$, and $18.3 \%$, respectively. This increased supply of branch-chained VFA likely contributed to the corresponding increases in NDFD because ruminal cellulolytic bacteria require them for optimal growth (Liu et al., 2009).

Increasing the dose of EFE 13D resulted in no effects on $\mathrm{NH}_{3} \mathrm{~N}$, linear $(P<0.10$, tendency) and quadratic $(P<0.01)$ increases in concentrations of acetate and valerate, respectively, and cubic effects on other fermentation measures $(P<0.05$; Table 3$)$. Total VFA concentration was increased $(P<0.05)$ by all doses of EFE 13D $(8.1,5.9,6.3$, and $11.4 \%$ for $0.5 \times, 1 \times, 2 \times$, and $3 \times$, respectively), largely due to increases $(P<$ $0.05)$ in propionate concentration at the $0.5 \times, 2 \times$, and $3 \times$ doses (11.0, 9.2 and 16.5\%, respectively). Butyrate concentration was only increased by the $3 \times$ dose (16.5\%), and acetate concentration was unaffected by dose. Consequently, the A:P ratio was decreased by all doses of EFE 13D. Concentrations of isobutyrate $(P<$ $0.05 ; 26.5,17.5,20.1$, and $31.8 \%)$ and isovalerate $(P$ $<0.05 ; 17.3,17.8,15.4$, and $19.7 \%$ ) were increased by the $0.5 \times, 1 \times, 2 \times$, and $3 \times$ doses, respectively. However, valerate concentration was only increased by the $1 \times$ and $2 \times$ doses $(P<0.05 ; 48.5$ and $27.4 \%$, respectively). Therefore, despite having the least activities and protein concentration of the EFE examined, EFE 13D had important beneficial effects on most digestibility and fermentation measures.

Increasing the dose of EFE $15 \mathrm{D}$ resulted in no polynomial effects on acetate, propionate, $\mathrm{NH}_{3} \mathrm{~N}$, and $\mathrm{pH}$, linear decreases $(P<0.01)$ in butyrate concentration and A:P ratio, a quadratic increase in TVFA concentration $(P<0.10$, tendency), and cubic effects on concentrations of isobutyrate, isovalerate, and valerate $(P<$ 0.01 , Table 3$)$. Only the $0.5 \times$ dose increased concentrations of TVFA (6.59\%), acetate $(6.97 \%)$, and isobutyrate $(6.88 \%)$ and the $0.5 \times$ and $2 \times$ doses increased $(P<$ $0.05)$ propionate concentration. All doses increased the isovalerate concentration, but butyrate concentration was decreased by the $3 \times$ dose $(-9.39 \%)$, the A:P ratio was reduced $(P<0.05)$ by the $2 \times$ and $3 \times$ doses $(-3.20$ and $4.37 \%$ ), and valerate concentration was decreased by all doses except $1 \times$. Beneficial fermentation product responses to applying EFE 15D were few and small relative to those for the other EFE. This reflects the minor increases in digestibility caused by this EFE, which would have limited availability of substrates for microbial fermentation.

\section{Experiment 2: Effects of EFE Dose on Measures of Preingestive Hydrolysis}

Increasing the dose of EFE $1 \mathrm{~A}$ increased DM loss $(P<0.05$, cubic $)$, increased concentrations of released FER $(P<0.01$, linear $)$, COU $(P<0.01$, quadratic $)$, and WSC $(P<0.01$, cubic $)$, and reduced concentrations of NDF, HEM, and $\mathrm{ADF}(P<0.05$, cubic; Table 4). The DM loss response presumably occurred via increased solubility and or particle size reduction, which increases the substrate surface area exposed to ruminal microbes and could thereby improve digestibility (Bansal et al., 2009). Consequently, the increases in digestibility measures by EFE $1 \mathrm{~A}$ may have been caused partly by the increased DM losses. Krueger and Adesogan (2008) also reported increased DM loss (1.8 percentage unit increase) in bahiagrass treated with a mixture of pure cellulase, xylanase, and ferulic acid esterase from Aspergillus spp., Orpinomyces spp., and Clostridium themocelllum applied at doses of 2, 2, and 1 $\mathrm{g} / 100 \mathrm{~g}$ of bahiagrass DM, respectively. In general, the $3 \times$ dose was or was among the most effective doses at increasing hydrolysis of NDF $(-6.0 \%)$, HEM $(-6.0 \%)$, and $\mathrm{ADF}(-5.8 \%, P<0.05)$ and releasing WSC, FER, and $\operatorname{COU}(112.8,27.2$, and $7.2 \%$, respectively; $P<$ $0.05)$ from cell walls. Such reductions in fiber concentration may increase voluntary intake because they reduce negative effects of gut fill on intake (Mertens, 2007). However, they will probably only increase digestion if the EFE also remove recalcitrant barriers to digestion, such as phenolic acids. The FER and COU released during the hydrolysis resulted from the action of ferulic and $p$-coumaric acid esterases. When bound to hemicellulose, these phenolic compounds decrease the rate and possibly the extent of polysaccharide digestion, especially when FER is cross-linked to lignin (Grabber et al., 1998). Therefore, their release from cell walls by EFE $1 \mathrm{~A}$ partially explains the increase in digestibility by the EFE. Beauchemin et al. (2004) and Adesogan (2005) emphasized the importance of including phenolic acid esterases in EFE products meant to improve forage digestibility, animal productivity, and nutrient use efficiency.

Applying increasing doses of EFE $2 \mathrm{~A}$ also resulted in increases in DM loss, hydrolysis of NDF, HEM, and $\mathrm{ADF}$, and release of WSC, FER, and COU $(P<0.05$, cubic; Table 4). As was the case for EFE $1 \mathrm{~A}$, the $3 \times$ dose was or was among the most effective $(P<0.05)$ doses at hydrolyzing NDF $(-11.6 \%)$ and HEM $(-18.8 \%$; $P<0.05)$ and hence increasing DM loss $(21.5 \%)$ and concentrations of WSC (242\%), FER (129\%), and COU $(35.5 \%)$. The increase in available sugars due to increasing the EFE $2 \mathrm{~A}$ dose likely explains the corresponding 
Table 4. Effects of the dose of different exogenous fibrolytic enzymes (EFE; 1A, 2A, 11C, 13D, and 15D, as described in Table 1) on DM loss and concentrations of NDF, hemicellulose (HEM), and ADF, water-soluble carbohydrates (WSC), ferulic acid (FER), and p-coumaric acid (COU) after preingestive hydrolysis of a 4 -wk regrowth of bermudagrass haylage (experiment 2 )

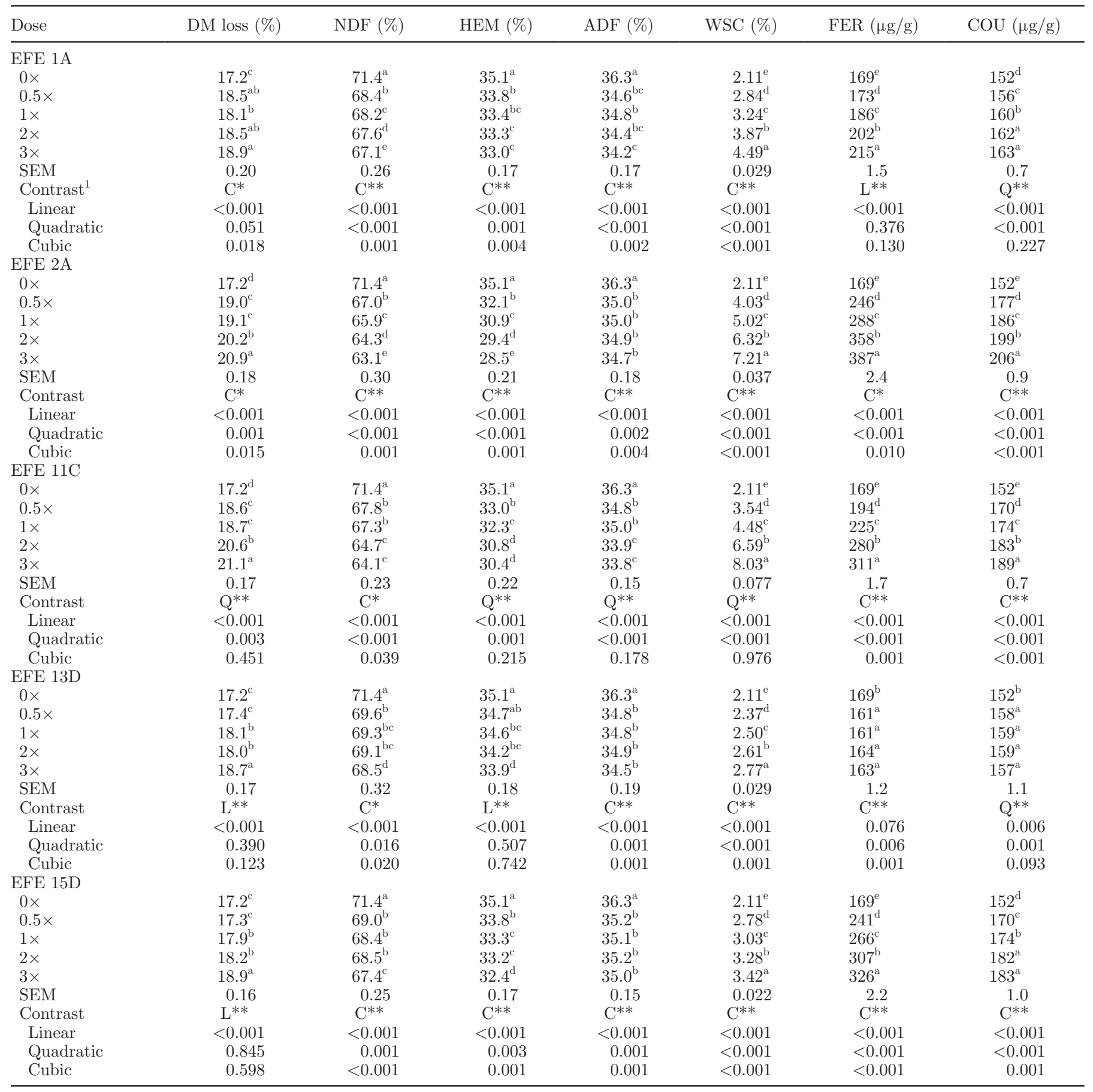

${ }^{\mathrm{a} e} \mathrm{e}$ Means within an EFE treatment within a column with different superscripts differed $(P<0.05)$.

${ }^{1}$ Linear (L), quadratic (Q), cubic (C), not significant (n.s.).

${ }^{+} P<0.10,{ }^{*} P<0.05$; ${ }^{* *} P<0.01$; n.s. $(P>0.10)$.

increases in propionate concentration by EFE $2 \mathrm{~A}$ and other EFE in our study. When availability of fermentable substrates in the rumen is high, the fermentation pattern shifts from one ending in acetic acid to propionic acid to dispose of excess reducing power (France and Dijkstra, 2005). Among all the EFE examined in 
the present study, EFE $2 \mathrm{~A}$ resulted in the greatest reductions in the hemicellulose fraction, reflecting its greater xylanase activity.

Applying EFE $11 \mathrm{C}$ at increasing doses also increased DM loss $(P<0.01$, quadratic $)$, hydrolysis of HEM, ADF $(P<0.01$, quadratic $)$, and NDF $(P<0.05$, cubic $)$, and release of WSC $(P<0.01$, quadratic $)$, FER, and $\mathrm{COU}$ $(P<0.01$, cubic; Table 4$)$. As for EFE $1 \mathrm{~A}$ and $2 \mathrm{~A}$, the $3 \times$ dose was or was among the most effective doses at increasing DM loss $(22.7 \%)$ and increasing release of WSC (281\%), FER (84.0\%), and COU $(24.3 \% ; P<$ 0.05). Krueger et al. (2008) also reported that an EFE rich in esterase activity from Humicola spp. increased release of ether-linked FER and ester-linked COU from bermudagrass cell walls. Among the EFE, 11C resulted in the greatest hydrolysis of $\mathrm{ADF}$, which agrees with the fact that only EFE 11C and 13D increased ADFD.

Increasing the dose of EFE 13D increased DM loss and HEM hydrolysis $(P<0.01$, linear $)$, increased hydrolysis of NDF and $\mathrm{ADF}(P<0.05$, cubic $)$, and increased saccharification of $\mathrm{BH}(P<0.01$, cubic; Table 4). Surprisingly and for unknown reasons, application of all doses of EFE 13D similarly reduced release of FER $(P<0.01$, cubic $)$ but increased release of COU $(P$ $<0.01$, quadratic). The $3 \times$ dose resulted in the greatest DM loss (8.7\%) and WSC concentration (31.3\%; $P<0.05)$ and among the greatest increases in NDF and HEM hydrolysis. In general, effects of EFE 13D on measures of preingestive hydrolysis were limited relative to those of the other EFE, reflecting its low enzymatic activities and protein concentration. Nevertheless, it increased all measures of in vitro digestibility, perhaps because it contained important unmeasured activities and auxiliary proteins (e.g., swollenin, polysaccharide monooxygenase).

Applying increasing doses of EFE 15D increased DM loss $(P<0.01$, linear $)$ and increased hydrolysis of NDF, $\mathrm{HEM}$, and $\mathrm{ADF}$ and release of WSC, FER, and $\mathrm{COU}$ $(P<0.01$, cubic; Table 4). Application of EFE 15D reduced ADF concentration, but all doses had the same effect $(P>0.05)$. In contrast, the $3 \times$ dose resulted in the least NDF $(-5.6 \%)$ and HEM $(-7.7 \%)$ concentrations, the greatest DM loss $(9.9 \%)$, and the greatest concentrations of WSC (62.1\%) and FER (92.9\%), whereas the $2 \times$ and $3 \times$ dose resulted in the greatest COU concentration $(20.4 \% ; P<0.05)$. In general, EFE $15 \mathrm{D}$ seemed more effective at increasing preingestive hydrolysis than EFE 13D; yet, unlike the latter, it had few and relatively small beneficial effects on most in vitro digestibility and fermentation measures. Krueger et al. (2008) also reported that an EFE from Humicola spp. increased preingestive hydrolysis but did not improve the NDFD of Tifton 85 bermudagrass hay. These responses suggest that EFE $15 \mathrm{D}$ can only hydrolyze easily accessible fiber fractions but cannot remove the main barriers to fiber digestion by ruminal microbes. Developing methods to more precisely identify and accurately quantify such barriers will facilitate development of more effective EFE products.

The current research is 1 of 4 studies aimed at improving the use of EFE to improve the performance of lactating dairy cows. A chronology and summary of the studies was given by Adesogan et al. (2014). The most promising readily available EFE identified in the current study (2A) was tested in lactating dairy cows at the dose that maximized the increase in NDFD per unit of EFE used. Application of EFE 2A increased intakes of DM, OM, CP, and FCM and milk fat production by the lactating dairy cows (Romero et al., in press), which confirms that the in vitro screening model used in the current study is useful for identifying enzymes and enzyme doses that can increase the performance of lactating dairy cows.

\section{CONCLUSIONS}

Increasing the EFE dose resulted in increased preingestive fiber hydrolysis of $\mathrm{BH}$, as well as increases in in vitro digestion and fermentation, but the extent and nature of the responses differed with the EFE and dose. These results indicate that EFE doses can be manipulated to increase preingestive fiber hydrolysis and digestion, which might increase the supply of nutrients to lactating cows fed enzyme-treated $\mathrm{BH}$. In particular, the consistent increase in sugar release as doses of each of the EFE increased implies increased supply of highly available substrates for rumen microorganisms. The highest EFE doses were consistently the most effective at increasing NDF and HEM hydrolysis and releasing WSC, but they were not the most effective at increasing in vitro digestibility or fermentation. This indicates that using measures of preingestive hydrolysis, such as release of WSC, to choose doses that will increase animal responses will probably be misleading. Baseline EFE doses examined in the current study were recommended by the manufacturers such that some EFE were applied at higher doses than others. Based on their ability to increase NDFD, EFE with lower baseline manufacturer-stipulated doses (1A and $2 \mathrm{~A}$ ) benefited from increasing the dose, whereas those with greater baseline doses (13D and 15D) benefited from reducing the dose. Consequently the optimal dose for the former was $2 \times$ the baseline dose, whereas that for the latter was $0.5 \times$ the baseline dose. The best dose for EFE 11C, which had an intermediate baseline dose, was the manufacturer-stipulated dose. Dose rates that 
enhanced digestibility also typically increased fermentation product concentrations and reduced the A:P ratio, and hence increased energetic efficiency.

\section{ACKNOWLEDGMENTS}

We gratefully acknowledge the statistical assistance of James Colee (University of Florida- Institute of Food and Agricultural Sciences Statistical Consulting Unit). This project was funded by a USDA-Tropical and Subtropical Agricultural Research grant.

\section{REFERENCES}

Adesogan, A. T. 2005. Improving forage quality and animal performance with fibrolytic enzymes. Pages 91-109 in Florida Ruminant Nutrition Symposium Proc., University of Florida-IFAS, Gainesville, FL.

Adesogan, A. T., Z. X. Ma, J. J. Romero, and K. G. Arriola. 2014. Improving cell wall digestion and animal performance with fibrolytic enzymes. J. Anim. Sci. 92:1317-1330.

AOAC International. 2000. Official Methods of Analysis. 17th ed. AOAC International, Arlington, VA.

Bansal, P., M. Hall, M. J. Realff, J. H. Lee, and A. S. Bommarius. 2009. Modeling cellulase kinetics on lignocellulosic substrates. Biotechnol. Adv. 27:833-848.

Beauchemin, K. A., D. Colombatto, and D. P. Morgavi. 2004. A rationale for the development of feed enzyme products for ruminants. Can. J. Anim. Sci. 84:23-36.

Beauchemin, K. A., D. Colombatto, D. P. Morgavi, and W. Z. Yang 2003. Use of exogenous fibrolytic enzymes to improve feed utilization by ruminants. J. Anim. Sci. 81:37-47.

Bergman, E. N. 1990. Energy contributions of volatile fatty acids from the gastrointestinal tract in various species. Physiol. Rev. 70:567-590.

Bio-Rad. 2011. Overview and strategies for bio-organic molecule purification. Accessed Nov. 10, 2013. http://www.bio-rad.com/ webroot/web/pdf/lsr/literature/Bulletin_1928.pdf.

Bommarius, A. S., A. Katona, S. E. Cheben, A. S. Patel, A. J. Ragauskas, K. Knudson, and Y. Pu. 2008. Cellulase kinetics as a function of cellulose pretreatment. Metab. Eng. 10:370-381.

Bradford, M. M. 1976. A rapid and sensitive method for the quantitation of microgram quantities of protein utilizing the principle of protein-dye binding. Anal. Biochem. 72:248-254.

Colombatto, D., and K. A. Beauchemin. 2003. A proposed methodology to standardize the determination of enzymic activities present in enzyme additives used in ruminant diets. Can. J. Anim. Sci. $83: 559-568$.

Colombatto, D., D. P. Morgavi, A. F. Furtado, and K. A. Beauchemin. 2003. Screening of exogenous enzymes for ruminant diets: Relationship between biochemical characteristics and in vitro ruminal degradation. J. Anim. Sci. 81:2628-2638.

Dean, D. B., A. T. Adesogan, N. Krueger, and R. C. Littell. 2005. Effect of fibrolytic enzymes on the fermentation characteristics, aerobic stability, and digestibility of bermudagrass silage. J. Dairy Sci. 88:994-1003.

Dimarogona, M., E. Topakas, and P. Christakopoulos. 2013. Recalcitrant polysaccharide degradation by novel oxidative biocatalysts. Appl. Microbiol. Biotechnol. 97:8455-8465.

DuBois, M., K. A. Gilles, J. K. Hamilton, P. A. Rebers, and F. Smith 1956. Colorimetric method for determination of sugars and related substances. Anal. Chem. 28:350-356.

Eun, J. S., and K. A. Beauchemin. 2008. Relationship between enzymic activities and in vitro degradation of alfalfa hay and corn silage. Anim. Feed Sci. Technol. 145:53-67.

France, J., and J. Dijkstra. 2005. Volatile fatty acid production. Pages 157-176 in Quantitative Aspects of Ruminant Digestion and Me- tabolism. 2nd ed. J. Dijkstra, J. M. Forbes, and J. France, ed. CABI Publishing. Oxfordshire, UK.

Goering, H. K., and P. J. Van Soest. 1970. Forage fiber analysis (apparatus, reagents, procedures, and some applications). Agric. Handbook No. 379. Agricultural Research Service, USDA, Washington, DC.

Gorka, P., Z. M. Kowalski, P. Pietrzak, A. Kotunia, R. Kiljanczyk, J. Flaga, J. J. Holst, P. Guilloteau, and R. Zabielski. 2009. Effect of sodium butyrate supplementation in milk replacer and starter diet on rumen development in calves. J. Physiol. Pharmacol. 60:47-53.

Grabber, J. H., J. Ralph, and R. D. Hatfield. 1998. Ferulate cross-links limit the enzymatic degradation of synthetically lignified primary walls of maize. J. Agric. Food Chem. 46:2609-2614.

Hanna, W. W., and L. E. Sollenberger. 2007 Tropical and subtropical grasses. Pages 245-256 in Forages: The Science of Grassland Agriculture. R. F. Barnes, C. J. Nelson, K. J. Moore, and M. Collins, ed. Blackwell Publishing, Ames, IA.

Krueger, N. A., and A. T. Adesogan. 2008. Effects of different mixtures of fibrolytic enzymes on digestion and fermentation of bahiagrass hay. Anim. Feed Sci. Technol. 145:84-94.

Krueger, N. A., A. T. Adesogan, C. R. Staples, W. K. Krueger, D. B. Dean, and R. C. Littell. 2008. The potential to increase digestibility of tropical grasses with a fungal, ferulic acid esterase enzyme preparation. Anim. Feed Sci. Technol. 145:95-108.

Kung, L., Jr., R. J. Treacher, G. A. Nauman, A. M. Smagala, K. M. Endres, and M. A. Cohen. 2000. The effect of treating forages with fibrolytic enzymes on its nutritive value and lactation performance of dairy cows. J. Dairy Sci. 83:115-122.

Lai, K. K., G. L. Lorca, and C. F. Gonzalez. 2009. Biochemical properties of two cinnamoyl esterases purified from Lactobacillus johnsonii strain isolated from stool samples of diabetes-resistant rats. Appl. Environ. Microbiol. 75:5018-5024.

Liu, Q., C. Wang, W. Z. Yang, B. Zhang, X. M. Yang, D. C. He, P. Zhang, K. H. Dong, and Y. X. Huang. 2009. Effects of isobutyrate on rumen fermentation, lactation performance and plasma characteristics in dairy cows. Anim. Feed Sci. Technol. 154:58-67.

Mertens, D. R. 2007. Digestibility and intake. Pages 487-508 in Forages: The Science of Grassland Agriculture. R. F. Barnes, C. J. Nelson, K. J. Moore, and M. Collins, ed. Blackwell Publishing, Ames, IA.

Mohammed, R., S. M. McGinn, and K. A. Beauchemin. 2011. Prediction of enteric methane output from milk fatty acid concentrations and rumen fermentation parameters in dairy cows fed sunflower, flax, or canola seeds. J. Dairy Sci. 94:6057-6068.

Muck, R. E., and J. T. Dickerson. 1988. Storage temperature effects on proteolysis in alfalfa silage. Trans. ASAE 31:1005-1009.

Newman, Y. 2007. Costal vs. Tifton 85 Bermudagrass for Horses.Facts \& Myths. University of Florida, IFAS Extension. Accessed Nov. 10, 2013. http://cflag.ifas.ufl.edu/documents/2007EquineInstit/ CoastalvsT-85.pdf.

Noel, R. J., and L. G. Hambleton. 1976. Collaborative study of a semi automated method for determination of crude protein in animal feeds. J. Assoc. Off. Anal. Chem. 59:134-140.

Nsereko, V. L., K. A. Beauchemin. D. P. Morgavi, L. M. Rode, A. F. Furtado, T. A. McAllister, D. Iwaasa, W. Z. Yang, and Y. Wang. 2002. Effect of a fibrolytic enzyme preparation from Trichoderma longibrachiatum on the rumen microbial population of dairy cows. Can. J. Microbiol. 48:14-20.

Oba, M., and M. S. Allen. 1999. Evaluation of the importance of the digestibility of neutral detergent fiber from forage: Effects on dry matter intake and milk yield of dairy cows. J. Dairy Sci. $82: 589-596$.

Rinne, M., S. Jaakkola, and P. Huhtanen. 1997. Grass maturity effects on cattle fed silage-based diets. 1. Organic matter digestion, rumen fermentation and nitrogen utilization. Anim. Feed Sci. Technol. $67: 1-17$.

Romero, J. J., M. A. Zarate, K. G. Arriola, C. F. Gonzalez, C. SilvaSanchez, and A. T. Adesogan. Screening exogenous fibrolytic enzymes preparations for improved in vitro digestibility of bermudagrass haylage. J. Dairy Sci. 10.3168/jds.2014-8059. 
Romero, J. J., M. A. Zarate, O. C. M. Queiroz, J. H. Han, J. H. Shin, C. R. Staples, W. F. Brown, and A. T. Adesogan. 2013. Fibrolytic enzyme and ammonia application effects on the nutritive value, intake, and digestion kinetics of bermudagrass hay in beef cattle. J. Anim. Sci. 91:4345-4356.

Sanchez, W. K., C. W. Hunt, M. A. Guy, G. T. Pritchard, B. I. Swanson, T. B. Warner, and J. M. Higgins. 1996. Effect of fibrolytic enzymes on lactational performance of dairy cows. J. Dairy Sci. 79(Suppl. 1):183 (Abstr).

Selig, M. J., E. P. Knoshaug, W. S. Adney, M. E. Himmel, and S. R. Decker. 2008. Synergistic enhancement of cellobiohydrolase performance on pretreated corn stover by addition of xylanase and esterase activity. Bioresour. Technol. 99:4997-5005.

Staples, C. R. 2003. Bermudagrass: Growing, storing, and feeding for dairy animals. Vol. 2013. IFAS Extension, Gainesville, FL. Accessed Nov. 10, 2013. http://edis.ifas.ufl.edu/pdffiles/DS/ DS13100.pdf.
Van Soest, P. J. 1994. Nutritional Ecology of the Ruminant, 2nd ed. Cornell. University Press, Ithaca, NY.

Van Soest, P. J., J. B. Robertson, and B. A. Lewis. 1991. Methods for dietary fiber, neutral detergent fiber and non-starch polysaccharides in relation to animal nutrition. J. Dairy Sci. 74:3583-3597.

Wood, T. M., and K. M. Bhat. 1988. Methods for measuring cellulase activities. Pages 87-112 in Methods in Enzymology. W. A. Wood and S. T. Kellogg, ed. Vol. 160. Academic Press, London, UK.

Zhang, Y. H. P., M. E. Himmel, and J. R. Mielenz. 2006. Outlook for cellulose improvement: Screening and selection strategies. Biotechnol. Adv. 24:452-481.

Zhang, Y. H. P., and L. R. Lynd. 2004. Toward and aggregated understanding of enzymatic hydrolysis of cellulose: Noncomplexed cellulose systems. Biotechnol. Bioeng. 88:797-824. 